\title{
An Examination of Women's Rights in Medieval England
}

\author{
Brittany Thaxter
}

In medieval England, Lisa Bitel writes, "women rise from medieval documents as shadows marked only by affiliation to individual men." 1 Before marriage, this affiliation was to fathers and brothers, and after marriage to husbands. As Bitel points out, "men [...] generated rules for how women should behave and decided what was to happen when a woman erred". 2 This was necessary because, as one medieval source claimed, "women are timorous, feeble, needful of many things, busy about many trifles, full of words and like unto a ruinous house that must be underset and upholden with many small props." ${ }^{3}$ It was the role of men to provide safety, care and security for the women in their families and surrounding community. ${ }^{4}$ The role of protector came to define a man's masculinity, while being protected was the definition of a woman's femininity. ${ }^{5}$ Since men were in charge of law making and governing, the laws of medieval England were ostensibly designed to ensure women were suitably "protected." In fact, as this paper will explore, paternalism was used as a justification and was consequently articulated through the legal system in pre-modern England to reify the subjugation of women within society.

Pre-modern England was completely submersed in Christian thought and structured as a patriarchy. The society was generally collective, meaning that the individual was only seen as a part of the larger community. This idea was represented in the political theory, the body politic that highlighted not only the collective mentality of the society but also the hierarchical properties of the collective. ${ }^{6}$ Not only was everyone defined in relation to the whole, they also all had a structured place and specific role to play. For women, these roles were mostly domestic and strictly enforced through religious and secular governing bodies.

Average life spans were short, and mortality was high. ${ }^{7}$ This was only exacerbated by the Black Death that raged from 1348-49, with cases occurring even into the midseventeenth century. This was also combined with high levels of malnutrition and starvation, along with strenuous labour. ${ }^{8}$ Both labour and procreation started at a young age. Medieval historian Jennifer Ward states that the life of most women consisted of a cycle of birth, marriage, motherhood and death. A woman's life was centered on the family, so she resided within a domestic space that consisted of those who were related to her through blood and marriage. ${ }^{9}$ Her primary role was to raise the children and maintain the

\footnotetext{
${ }^{1}$ Lisa M. Bitel, Women in early medieval Europe, 400-1100 (Cambridge: Cambridge University Press, 2002), 1.

2 Ibid., 3.

3 Karen Jones, Gender and Petty Crime in Late Medieval England: The Local Courts in Kent, 1460-156

(Woodbridge: The Boydell Press, 2006), 4.

${ }^{4}$ Ibid. 4.

${ }^{5}$ Bitel, Women, 3.

${ }^{6}$ Ernest Kantorowicz, The King's Two Bodies: A Study in Mediaeval Political Theology (Princeton: Princeton University Press, 1957), 9.

7 Jennifer Ward, Women in England/Middle Ages (London: Hambledon Continuum A Continuum Imprint, 2006), 3.

8 Ibid, 2.

${ }^{9}$ Bitel, Women, 3.
} 
household. However, it is worth noting that at this time, most people lived off the land, so the work of maintaining the fields and the home was often shared between the husband and wife. ${ }^{10}$

A woman's role within marriage was largely defined by the ideals of the Church. The Church long regarded women as the lesser sex, dependent on men because of their supposed irrationality and their tendency towards sin. These perspectives were rooted in the biblical story of Adam and Eve. ${ }^{11}$ According to the Church, there were two types of women, the 'Eve' archetype, the corruptible or corrupting women, and the 'Mary' archetype, the divine or pious inspirer of man. ${ }^{12}$ Women were supposed to strive to fit the 'Mary' mould, but very few actually achieved this, especially those women who were married. ${ }^{13}$

The medieval Church's view on marriage was strongly influenced by the Biblical letters of Paul. In the first letter Paul wrote to the Corinthians, he wrote that "a woman's body does not belong to her alone but also to her husband." Additionally, "an unmarried woman or virgin is concerned about the Lord's affairs: her aim is to be devoted to the Lord in both body and spirit. But a married woman is concerned about the affairs of this worldhow she can please her husband", and "a woman is bound to her husband as long as he lives." 14 In a letter to the Ephesians, Paul ordered: "wives, submit yourselves to your own husbands as you do to the Lord. For the husband is the head of the wife as Christ is the head of the church" and "the wife must respect her husband."15 These passages from scripture supported the Church's view that a wife's principal duty was to serve her husband. It was not until after the twelfth-century that the church began to view marriage as a partnership, emphasizing consent and respect between both husband and wife. However, this remained an ideal that was not reflected often in everyday life. ${ }^{16}$

If a man failed to 'protect' his wife from harm, the first tendency of the social collective was to question the measure of the wife's subservience. A man's role to protect her was defined by her ability to serve him; his protection came at the price of her servitude. This attitude was evident in a court document that discussed the marriage of Henry Cook and his (importantly) unnamed wife. ${ }^{17}$ The woman claimed that her husband had a "malevolent mind towards her" and was also taking part in an adulterous relationship with several other women. Ultimately, the court decided that she must remain with him and "humble and familiaris with her husband and not [...] insulting" because she abandoned her spousal duties and left him because his cruelty. ${ }^{18}$ According to another court record, a man named John Page sold his wife to another man for a pig. ${ }^{19} \mathrm{He}$ later

${ }^{10}$ Ibid., 3.

11 Ward, Women, 3.

12 Lucia Zedner, Women, Crime, and Custody in Victorian England (New York: Oxford University Press, 1991),

11.

13 Ibid., 11.

141 Corinthians 7:4-39 (New International Version)

15 Ephesians 5:22-33 (New International Version)

16 Ward, Women, 4.

17 "Manorial Marriage and Sexual Offense Cases," in Medieval Sourcebook, edited by Paul Halsall, Jan 1996. http://www.fordham.edu/Halsall/source/manor-marr1.asp

18 Ibid.

${ }^{19}$ Ibid. 
came to the conclusion that it was not a fair trade and decided to take her back without paying the 'proper amount' for her return. ${ }^{20}$ This case emphasized the view of women as property; they were at times used as a form of currency among families, and in this particular instance, even an equivalent to live stock. What made a woman a desirable marriage prospect was the size of her dowry. Medieval historian Barbara Hanawalt calls this the "marriage market," in which it was as if women were stocks being bought and sold publicly to the highest bidder. ${ }^{21}$ Once acquired, a wife was the property of her husband.. ${ }^{22}$

A woman's body was not her own. Even an act of rape was evaluated based on the woman's marital status rather than on her personhood. ${ }^{23}$ If a virgin was raped, the crime was punishable by death, because her chances at marriage had been lowered and so too had her value to her family. ${ }^{24}$ If the rape victim was married or a widow, then the crime was only punished with corporal punishment, since this crime had less impact on the men in the woman's life. ${ }^{25}$ This demonstrated that women's lawful means of defence against crimes committed against their bodies were contingent on their status as property.

While women were not considered individual people under the law; they were given the right to retribution, through their husband or guardian, in the case of injury. ${ }^{26} \mathrm{~A}$ woman's legal rights were defined only when she was a wife, due to unity of person, meaning that because a husband and wife were of the same flesh her rights fell under his. ${ }^{27}$ Also, due to her social existence as property, a man had the right to punish his wife corporally. Even though limitations existed, due to the nature of the justice system, a woman had almost no way of seeking retribution for a breach of these limitations. ${ }^{28}$ In one case when a woman left her husband because he was cruel to her, the Church forced her to go back to living with him as long as he promised not to do it again and expressed sadness when they had sex. ${ }^{29}$

For the Spanish philosopher Gratian, the primary role of marriage was procreation. ${ }^{30}$ Since a woman's primary purpose in marriage was to bear children, her reproductive rights were severely limited. By the beginning of the twelfth century, laws pertaining to childbirth began to appear throughout England. ${ }^{31}$ Most of these codes spelled out penalties if a woman's fertility or her fetus was compromised. These penalties were considered to be held in the highest esteem, and in some cases, crimes against childbearing

\footnotetext{
20 Ibid.

21 Barbara Hanawalt, Wealth of Wives: Women, Law, and Economy in Late Medieval London (Cary: Oxford University Press, 2007), 51.

22 Ibid., 118.

23 Barbara Hanawalt, Of Good and Ill Repute: Gender and Social Control in Medieval England (Oxford: Oxford University Press, 1998), 126.

24 Ibid.

25 Ibid.

${ }^{26}$ Barbara Hanawalt, Medieval Crime and Social Control (Minneapolis: University of Minnesota Press, 1998), 158.

27 Ibid.

28 Hanawalt, Wealth of Wives, 51.

29 “Gratian: On Marriage (dictum post C.32.2.2)," in Medieval Sourcebook, edited by Paul Halsall, Jan 1996. http://www.fordham.edu/Halsall/source/gratian1.asp.

30 Ibid.

31 Fiona Stoertz-Harris, "Pregnancy and Childbirth in Twelfth and Thirteenth Century French and English Law," Journal of the History of Sexuality 21, no. 2 (2012): 266.
} 
women were classified as felonies. ${ }^{32}$ Protective rights for pregnant women were predicated on their status as mothers, rather than as legal persons. For instance, if a pregnant woman was assaulted, the severity of the punishment was based on the amount of damage done to the unborn child, rather than the damage done to the woman. If the unborn child was discovered to be a male the penalty was even worse. ${ }^{33}$ According to these laws, a woman was merely the vessel in which the child was carried, and as such her rights were determined through her connection to another person.

Like men, women faced legal consequences if they broke laws. Some studies suggest that men had a higher conviction rate then women, but Walker argues that this was not the case. ${ }^{34}$ She argues that when comparing like crimes among men and women, there are two differences, neither of which is the conviction rate. ${ }^{35}$ First, the punishment for women was less severe. In a case where a man might have been publicly flogged, a woman might only be fined. This difference is attributable to the role of protectors that men were supposed to play in the lives of the women in their community. The second difference is that occurrences of crime among women were fewer, thus skewing the conviction data. ${ }^{36}$ Hanawalt explains that women did not commonly commit crimes, and when they did they were private crimes, such as stealing food to feed the family. Women so rarely appeared in public that they rarely had the opportunity to be caught committing crimes. ${ }^{37}$ It is possible, Walker argues, that the lack women in law records does not necessarily mean they did not commit crimes; rather, fewer women than men were brought to trial because home-based, patriarchal penal systems tended to punish crime before it reached the court system. ${ }^{38}$ Men had the right to dole out corporal punishment, so most women's minor crimes were punished privately between the accuser and the woman's husband. Walker points out as well that some crimes were household crimes, suggesting that while the women often participated in the crime, it was their father or husband that ultimately received the punishment. ${ }^{39} \mathrm{~A}$ female participant in a "household crime" was often viewed as incapable of having made the decision to partake on her own. The crime was still the responsibility of the man. This escape from punishment is one example of the legal system could work to a woman's advantage.

Unlike almost anywhere else in Europe, English women had the right to inherit and own land; they could own their own business, incur debts, and even legally challenge their deceased husband's final will and testament in order to be awarded the dower promised to them by the British legal code. ${ }^{40}$ Though a woman was considered property, there were laws that allowed, under very specific circumstances, them to own and inherit land in England. ${ }^{41}$ Lady Agnes Say was an example of a woman supporting herself with an

\footnotetext{
32 Ibid., 266.

33 Ibid., 269.

${ }^{34}$ Garthine Walker, Crime, Gender and Social Order in Early Modern England (Cambridge: University Press, 2003), 176.

35 Ibid., 179.

36 Ibid.

${ }^{37}$ Hanawalt, Of Good and Ill Repute, 7.

38 Walker, Crime, 9-10.

39 Ibid.

40 Ibid., 51-213.

${ }^{41}$ Hanawalt, Wealth of Wives, 50.
} 
inheritance. After four marriages, Agnes eventually died a "widow of sound mind." 42 The first quarter of her will was spent relieving people of financial debts owed to her. As demonstrated in this will, women could gain financial independence later in life, based on inheritance. ${ }^{43}$ It is also worth noting that in this particular will, most of the inheritance was left to other women, some related, and others not. ${ }^{44}$ However, if any of these women named in the will were married or under the guardianship of a man, the land was to be managed by him. ${ }^{45}$

Widows were capable of manipulating the law in their favour by challenging their deceased husband's will in court. Known as the dower under English law, a wife was entitled to one third of the wealth after her husband's death. This was supposed to be representative of the dowry that she had brought into the marriage. There are instances throughout the medieval time period where women took their husbands' will to court and fought to ensure that she received that to which she was entitled. ${ }^{46}$ This legal benefit could only be accessed with the help of other 'honest' men, meaning that a woman either had to remarry or have a son who could attest to her right to the inheritance. The inherited wealth was only hers in life, and she was not able to bequeath it to someone else unless like Lady Agnes Say, the woman was to remarry, this could lead to problems because her inherited wealth would legally become that of her husband's, until he died and she was again bequeathed a third of his wealth. ${ }^{47}$ This is what a Venetian visiting England during the $12^{\text {th }}$ century described as "secreting away some extra wealth." ${ }^{48}$ In London, a woman could inherit land or property at the age of sixteen. Before coming of age, the property was held by a guardian. ${ }^{49}$ Most commonly, however, women who were young and not yet married would not be allowed to access their inheritance until after they were wed, when their husbands collected it on their behalf. ${ }^{50}$ The supposed freedom of inheritance was in some ways superficial.

In many other realms across medieval Europe, women could not inherit land, and the rules pertaining to corporal punishment were weaker than in England. It has also been observed that England did not have long lines of patrilineage, as in other European countries of the time. In fact, England had "more horizontal social ties then the vertical ones common [in other European countries]" because London's laws allowed a large amount of London's real estate and liquid wealth to be passed through the hands of women. ${ }^{51}$ This was because a newly widowed woman with a sizable dower to manage was a very promising marriage prospect, and as a result, wealth tended to be spread around. In contrast, in Italy widows were often viewed as burdens, and so often only remarried into the families of which they had already been part, as a form of social and financial security. ${ }^{52}$

\footnotetext{
42 Jones, "Testament of a City-Dwelling Knight's Widow."

43 Ibid.

${ }^{44}$ Ibid.

${ }^{45}$ Hanawalt, Wealth of Wives, 51.

${ }^{46}$ Hanawalt, Medieval Crime and Social Control, 164.

${ }^{47}$ Hanawalt, Wealth of Wives 95; Jones, "Testament of a City-Dwelling Knight's Widow."

${ }^{48}$ Hanawalt, Wealth of Wives, 95.

49 Ibid., 51.

50 Ibid., 52.

51 Ibid., 96.

52 Ibid., 96.
} 
In England, even though a woman might have had little or no power at the beginning of her life, at the end, she might be in charge of wealth and business, based on the rights awarded to her through the English legal code. These rights were nevertheless steeped in English codes of patriarchy. A landowning woman had usually already been wed, and had most likely already had children. Hence, she had fulfilled her main social duties. She may thus have become entitled to some privilege, but not more fundamental equality..$^{33}$

Women also played an active role in the economy, often doing service-related jobs to help contribute to their household income, but they often had little to no control over these earnings. ${ }^{54}$ London law allowed for married women to be declared femmes soles, women registered with the mayor and responsible for their own trading, profits and debts, as long as they had the permission of their husbands. This served the purpose of protecting husbands from any poor business decisions a wife might make. ${ }^{55}$ Widows were allowed to inherit their deceased husband's business and carry on running it as long as it was bequeathed in the will and she had the help of kin to help administrate it. ${ }^{56}$ Such a woman could operate in business as long as she was of good repute, meaning that she had wellrespected men who could vouch for her honesty and integrity, and she maintained her other feminine duties as necessary.

It could be argued that the men governing English law were not intentionally oppressing women, but rather taking their role as their protectors and burden-bearers very seriously. The problem with paternalism of this sort was that, by declaring themselves protectors and guardians, men implied that women were unable to protect themselves. By thus constantly reifying their masculinity, men forced women to maintain a constructed inferiority, and fostered a system of inequality between the genders. While the intentions underlying the law codes were steeped in language of Church-defined "morality," they were still oppressive. Women were able to use the existing law code to their benefit in certain circumstances with the help of men, but primarily this was after husbands died and their primary social duties as wives and mothers were previously met.

The most troubling part of the English law code was the unity of person, whereby a wife and husband legally became one entity. In spite of this apparent unity, women were understood as distinct personae, indicating that their rights were not equal to those of their husband. Women's legal rights fell under the breadth of the husband's rights and responsibilities. ${ }^{57}$ Married women were thus defined by their marital status rather than as individuals, and a pregnant woman' s legal rights were secondary to those of her unborn fetus. ${ }^{58}$ Hence, the rights of women in Medieval England were generally variable. Factors such as who her aggressor was, her health condition and her marital status determined whether or not crimes committed against her were viewed as crimes in a court of law. Variable rights, contingent on a woman's social status as property, fell far short of full equality of all persons before the law. Thus, even the comparatively progressive legal code of medieval England served to ensure that oppressive patriarchal social structures were maintained.

\footnotetext{
53 Ibid., 98.

54 Ibid., 160.

55 Ibid., 213.

56 Ibid.

57 Hanawalt, Medieval Crime and Social Control, 158.

${ }^{58}$ Stoertz-Harris, “Pregnancy," 269.
} 


\section{Bibliography}

Bitel, Lisa M. Women in early medieval Europe, 400-1100. Cambridge: Cambridge University Press, 2002.

"Gratian: On Marriage (dictum post C.32.2.2)." In Medieval Sourcebook, edited by Paul Halsall. Jan 1996. http://www.fordham.edu/Halsall/source/gratian1.asp

Hanawalt, Barbara. 'Of Good and Ill Repute': Gender and Social Control in Medieval Europe. Cambridge: Cambridge University Press, 1998.

Medieval Crime and Social Control. Minneapolis: University of Minnesota Press, 1998.

Wealth of Wives: Women, Law, and Economy in Late Medieval London. Cary: Oxford University Press, 2007.

Jones, Karen. Gender and Petty Crime in Late Medieval England: The Local Courts in Kent, 1460-1560. Woodbridge: The Boydell Press, 2006.

Jones, Philip. "Testament of a city-dwelling knight's widow." Calendar of Plea and Memoranda Rolls of the City of London, A.D 1458-1482. Cambridge: University Press, 1961. http://users.trytel.com/ tristan/towns/florilegium/lifecycle/lcdth18.html

Kantorowicz, Eenest. The King's Two Bodies: A Study in Mediaeval Political Theology. Princeton: Princeton University Press, 1957.

"Manorial Marriage and Sexual Offense Cases." In Medieval Sourcebook, ed. Paul Halsall. Jan. 1996. http://www.fordham.edu/Halsall/source/manor-marr1.asp

Stoertz-Harris, Fiona. "Pregnancy and Childbirth in Twelfth and Thirteenth Century French and English Law." Journal of the History of Sexuality 21 no. 2 (2012): 263-281.

Walker, Garthine. Crime, Gender and Social Order in Early Modern England. Cambridge: University Press, 2003.

Ward, Jennifer. Women in England/Middle Ages. London: Hambledon Continuum, A Continuum Imprint, 2006.

Zedner, Lucia. Women, Crime, and Custody in Victorian England. New York: Oxford University Press, 1991. 